\title{
REVIEW
}

\section{Cell cycle and Alzheimer's disease: studies in non-neuronal cells}

\author{
Natividad de las Cuevas ${ }^{1 *}$, Úrsula Muñoz ${ }^{1 *}$, Fernando Bartolomé ${ }^{*}$, Noemí Esteras ${ }^{1}$, Carolina Alquezar ${ }^{1}$, \\ Ángeles Martín-Requero ${ }^{1,2}$
}

${ }^{1}$ Department of Cellular and Molecular Medicine, Centro de Investigaciones Biológicas (CSIC); ${ }^{2}$ Centro de Investigación Biomédica en Red de Enfermedades Raras (CIBERER), Madrid, Spain

*These authors contributed equally to this work.

Received $24^{\text {th }}$ February 2010.

Revised $27^{\text {th }}$ April 2010.

Published online $6^{\text {th }}$ May 2010.

\begin{abstract}
Summary
The most common cause of dementia in the elderly is Alzheimer disease (AD). In Europe, AD is a leading cause of death. The prevalence of this disease in developed countries is increasing because of very significant shifts in life expectancy and demographic parameters. AD is characterized by progressive cognitive impairment, resulting from dysfunction and degeneration of neurons in the limbic and cortical regions of the brain. Two prominent abnormalities in the affected brain regions are extracellular deposits of $\beta$-amyloid, and intracellular aggregates of tau protein in neurofibrillary tangles. The role of these features in AD pathogenesis and progression is not yet completely elucidated. Research over the last decade has revealed that the activation of cell cycle machinery in postmitotic neurons is one of the earliest events in neuronal degeneration in $\mathrm{AD}$. Here we summarize evidence to support the hypothesis that cell cycle alterations occur in cells other than neurons in AD sufferers. Immortalized lymphocytes from AD patients have show an enhanced rate of proliferation associated with G1/S regulatory failure induced by alterations in the cyclin/CDK/pRb/E2F pathway. In addition, these cells have a higher resistance to serum deprivation-induced apoptosis. These neoplastic-like features, cell cycle dysfunction and impaired apoptosis can be considered systemic manifestations of AD disease.
\end{abstract}

Key words: Alzheimer's disease; lymphocytes; cell cycle; cell survival; p27; p21; calmodulin; PI3K/Akt; ERK $1 / 2$

\section{INTRODUCTION}

Alzheimer's disease (AD) is a progressive neurodegenerative disorder affecting aged people; AD prevalence is approximately $1 \%$ between 65 and 69 years and is higher than $50 \%$ in individuals above 95 years. The predominant clinical manifestation is

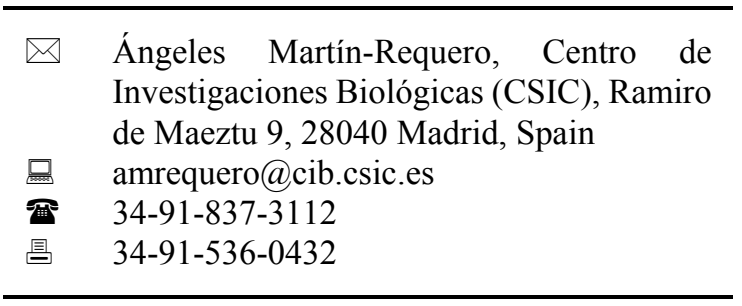

memory loss, but a number of other changes in brain functioning, including impairments in language and visual-spatial skills, and disorientation also characterize this disease. With increasing life expectancy across the world, dementia is a rapidly growing socioeconomic and medical problem. The hallmarks for $\mathrm{AD}$ are $\beta$-amyloid plaques, neurofibrillary tangles, and regionalized neuronal loss. However our understanding of the role that these features of $\mathrm{AD}$ play in the etiology of the disease remains incomplete.

$\mathrm{AD}$ is extremely complex and genetically heterogeneous. The majority of patients with the so-called "sporadic" disease exhibit clinical signs during the seventh decade, whereas individuals with inherited AD (FAD) often become demented in mid 
life. To date autosomal dominant FAD has been linked to the presence of mutations in the genes $A P P$, $P S 1$, and $P S 2$, which are genes encoding the amyloid precursor protein (APP), located in chromosome 21 or the presenilins PS1 or PS2 in chromosomes 14 and 1 respectively. The late-onset or sporadic AD has been associated with genetic factors modifying the risk of suffering AD. Notably, the risk of apoE allele type is a susceptibility locus with apoE4 showing a dose-dependent contribution to AD (Strittmatter et al. 1993). Various methods of genetic analysis indicate that additional genes predisposing to $\mathrm{AD}$ exist. A complete list of susceptibility genes associated with increased risk for $\mathrm{AD}$ can be found in http://alzgene.org (Bertram et al. 2007).

\section{CELL CYCLE AND AD}

Despite progress in uncovering many of the factors that contribute to the etiology of this disease, the cause of neuronal death is largely unknown. One promising theory to explain neurodegeneration in $\mathrm{AD}$ is that neuronal loss could be associated with cell cycle disturbances. This hypothesis receives support from evidence that a variety of cyclins and cyclin-dependent kinases (CDKs) are up-regulated in the brain of AD patients (Nagy et al. 1998), suggesting that elements that normally control cell cycle progression in proliferating cells may modulate neuronal death as well. Hippocampal and selected cortical neuronal populations in $\mathrm{AD}$ exhibit phenotypic changes characteristic of cells re-entering the cell division cycle (Arendt 2003), and it has been further demonstrated that a significant fraction of the hippocampal pyramidal and basal forebrain neurons have fully or partially replicated four independent loci of three different chromosomes (Yang et al. 2001). The successful duplication of DNA indicates that some neurons had completed the $\mathrm{S}$ phase of cell cycle (Mosch et al. 2007). These anomalies were not found in unaffected regions of $\mathrm{AD}$ brains or in the hippocampus of non-demented age-matched controls. Recent work has shown that cell cycle-related events are present many months before the appearance of plaques or signs of inflammation in brain of murine models of AD (Yang et al. 2006), as well as in brain of patients with Mild Cognitive Impairment (MCI) (Ueberham and Arendt 2005). MCI is a risk stage for development of AD within the next 3-5 years. Therefore, it appears that cell cycle dysfunction is implicated in disease onset and early development and it seems to confer selective vulnerability to neurons (Webber et al. 2005). Importantly, most of the $\mathrm{AD}$ pathological features, including $\beta$-amyloid, tau, presenilin mutations, oxidative stress, dystrophic neuritis, DNA damage and aneuploid are somehow related to cell cycle control, providing a link between cell cycle disturbances and neurodegeneration (Zhu et al. 2007, Żekanowski and Wojda 2009). A causal relationship between cell cycle re-entry and neurodegeneration has been recently reported in a transgenic mouse model in which conditional and neuron-specific expression of the proto-oncogene $c-M y c$ leads to cognitive deficit and neurodegeneration (Lee et al. 2009a). It is now assumed that adult neurons, rather than staying permanently postmitotic, must constantly keep their cell cycle in check (Herrup and Yang 2007). If control of neuronal cell cycle fails, the consequence is the entrance of neurons into an altered and vulnerable state, often leading to death (Zhu et al. 2007). Based on these findings, some authors have come to consider $\mathrm{AD}$ disease as an abortive neoplastic disorder, that is, a disease of the cell cycle, and thus, the knowledge of the intimate involvement of cell-cycle checkpoints in molecular pathogenesis of AD might be important for diagnostic purposes and particularly in the search for treatment strategies (see Lee et al. 2009b for a review).

\section{MITOTIC SIGNALS}

The search for factors responsible for the formation of neurofibrillary tangles and amyloid deposits has yielded several clues to the hypothesis that cell cycle-related phenomena is implicated in the accumulation of AD pathology. CDKs are involved in the phosphorylation of tau (Weishaupt et al. 2003), the main component of tangles as well as a key protein for cytoskeleton organization that occurs during neurite outgrowth and perhaps in aberrant neuronal sprouting (Webber et al. 2005). $\beta$-amyloid has been identified as mitogenic in vitro (Milward et al. 1992). APP may induce the activation of cell cycle proteins in neurons (Neve and McPie 2006). Conversely, cell cycle proteins that normally control the progression of cell cycle at the G1/S checkpoint are present in tangle bearing neurons (McShea et al. 2007). The accumulation of potentially mitogenic growth factors (EGF, bFGF) in diffuse amyloid deposits could represent the trigger that initiates the re-entry of neurons into the cell cycle (McShea et al. 1999). DNA damage induced by oxidative stress has been associated with overexpression of the tumor suppressor protein $\mathrm{p} 53$ and cell cycle reentry-induced apoptosis in cultured neurons (Kruman et al. 2004). 
p53 could activate cell cycle or apoptosis depending on the success of the DNA repairing process (Żekanowski and Wojda 2009). Other factors, including many of the identified risk factors for Alzheimer's disease, such as elevated plasma homocysteine levels, ageing, menopause, low thyroid levels, low level prolonged oxidative stress or head injury, can either represent mitogenic signalling for neurons or facilitate cell cycle re-entry in vulnerable neuronal populations (reviewed by Arendt 2003).

\section{CELLULAR AND ANIMAL MODELS}

Limitations in the use of the postmortem brain for examining molecular mechanisms underscore the need to develop cell or animal models representative of the pathogenesis that characterize AD. Thus, there has been a strong impetus in the last decade to develop a number of different transgenic mouse models of AD that overexpress the human FAD genes in the context of the mouse. This has proven to be a valuable resource in the study of APP processing and in the exploration and design of disease therapies (Morrissette et al. 2009). The AD mice show microglial activation, astrocytosis, and changes in neuronal cytoskeleton proteins including tau. Many of these model organisms have also been shown to have significant memory deficits. Although most of these mice don't show significant loss of neuronal bodies, cell cycle-related events appear to occur also in the mouse brain. Recently, it has been demonstrated in four different plaque bearing mice, that neurons in the most vulnerable areas have begun a true cell cycle (Yang et al. 2006).

An alternative strategy to study the pathogenesis of $\mathrm{AD}$ is the use of non-neuronal cells from patients. Numerous observations indicate that, while the predominant clinical expression arises from brain, $\mathrm{AD}$ has systemic expression at the cellular and molecular levels. Considerable precedent exists for studying AD with peripheral tissues, including lymphocytes, fibroblasts, and platelets (Etcheberrigaray and Ibarreta 2001, Casoli et al. 2008). The use of peripheral tissues complement studies of autopsy samples and provide a useful tool to investigate dynamic processes such as signal transduction mechanisms, oxidative metabolism, etc.

\section{CELL CYCLE DISTURBANCES IN NON-NEURONAL CELLS}

Work from our laboratory and others have shown cell cycle disturbances in peripheral cells, such as lymphocytes from $\mathrm{AD}$ patients, suggesting that dysfunction of the cell cycle is a more general phenomenon affecting cells other than neurons. Immortalized lymphocytes from $\mathrm{AD}$ patients showed altered response to mitogenic stimulation relative to control subjects (Urcelay et al. 2001, Nagy et al. 2002). Fibroblasts collected from AD patients also show an aberrant cell cycle-dependent $\mathrm{Ca}^{2+}$ response (Tatebayashi et al. 1995). We, and others have also found failure of the G1/S transition checkpoint, similar to that reported in AD brain, in lymphocytes from AD subjects (Nagy et al. 2002, de las Cuevas et al. 2003), and interestingly in MCI patients as well (Nagy et al. 2002, Zhou and Jia 2010).

We also found that lymphocytes from $\mathrm{AD}$ patients were more resistant to serum withdrawal-induced cell death (de las Cuevas et al. 2005), suggesting that control of cell fate depending on the presence or absence of growth stimulatory signals is impaired in peripheral cells from AD sufferers. These features might represent an adaptative response for $\mathrm{AD}$ cells that are exposed to chronic stress. It has been considered that susceptible neurons in AD survive for long time in a compromised way by delaying the apoptotic process, a mechanism termed abortosis or abortive apoptosis (Jellinger 2006).

\section{PROLIFERATIVE ACTIVITY OF IMMORTALIZED LYMPHOCYTES FROM CONTROL AND AD PATIENTS}

To investigate the distinct cell cycle regulation in $\mathrm{AD}$ at the systemic level, we performed a comparative study on cell proliferation, cell cycle profiles, and expression levels of key cell cycle regulatory proteins in lymphoblasts derived from control and late-onset AD subjects. These lymphoblastoid cell lines, obtained by infecting peripheral blood mononuclear cells with the Epstein Barr virus, retained the cellular response of freshly obtained lymphocytes, to serum addition or withdrawal (Bartolomé et al. 2007, Muñoz et al. 2008a).

Lymphoblasts from AD patients exhibited a serum dose-dependent enhanced rate of proliferation compared with cells from normal age-matched controls (Urcelay et al. 2001, de las Cuevas et al. 2003). AD lymphoblasts show cell cycle progress modifications such as a decrease of cells in G1, and an increased number of cells in $\mathrm{S}$ phase, together with altered expression and phosphorylation of several proteins involved in regulation of the G1/S transition check point (de las Cuevas et al. 2003, 2005, Muñoz et al. 2005). AD lymphoblasts showed increased 
phosphorylation of the retinoblastoma protein $(\mathrm{pRb})$ and other members of the family of pocket proteins compared with cell lines derived from normal age-matched controls (de las Cuevas et al. 2003, Muñoz et al. 2005). $\mathrm{pRb}$ is sequentially phosphorylated by two sets of protein kinases, the cyclinD/CDK4 and cyclin E/CDK2 complexes (Mittnacht 1998). The activity of the latter, was found to be enhanced in AD lymphoblasts (Muñoz et al. 2008a). Furthermore, we demonstrated that the increase in CyclinE/CDK2 activity was not due to changes in the expression levels of either cyclin E or CDK2, but rather, to the decreased levels of the CDK inhibitor p27 found in AD lymphoblasts (de las Cuevas et al. 2003, Muñoz et al. 2005).

Once $\mathrm{pRb}$-related proteins are phosphorylated, the transcription factor E2F is released and activated (Weinberg 1995). Accordingly, nuclear extracts from AD lymphoblasts showed reduced E2F-DNA binding activity as determined by EMSA analysis (de las Cuevas et al. 2005). In contrast the activity of NF- $\kappa B$ was found to be decreased in lymphocytes from $\mathrm{AD}$ patients, and was not related to the serum-induced enhanced proliferation, but associated instead with decreased vulnerability of AD cells to serum deprivation (de las Cuevas et al. 2005).

Two different reports have shown that freshly obtained lymphocytes from $\mathrm{AD}$ patients are less sensitive to G1/S transition blockers, thus suggesting a failure of the G1/S checkpoint function (Nagy et al. 2002, Zhou and Jia 2010). These authors also found these cell cycle alterations in MCI or mild-AD patients.

Further work focused in delineating the molecular mechanisms underlying the p27 down-regulation in $\mathrm{AD}$ cells. It was found that this effect was due to increased p27 degradation. A shorter half-life of the p27 protein was detected in AD lymphoblasts as compared with control cells (Muñoz et al. 2008a). p27 proteolysis is a three-step process that requires phosphorylation at Thr187, recognition by the F-box protein SKP2, ubiquitination, and degradation by the $26 \mathrm{~S}$ proteasome. Increased phosphorylation of p27 protein at Thr187 in AD cells, rather than changes in the $26 \mathrm{~S}$ proteasome machinery, seems to account for decreased p27 levels. An inverse relationship between phospho-p27 and p27 content was found, while total proteasome activity and accumulation of ubiquitin-tagged proteins did not change significantly (Muñoz et al. 2008a, b).

Interestingly, the enhanced proliferative activity and changes in cell cycle regulatory proteins, can be modulated pharmacologically by treating AD cells with the anti-inflammatory cyclopentenone 15-deoxy-prostaglanding $\mathrm{J}_{2}$ or simvastatin (Muñoz et al. 2005, 2008b, Sala et al. 2008). Therefore these observations provide a plausible explanation for the reported apparent benefits of these drugs preventing or delaying the clinical features of AD (Stewart et al. 1997, Wolozin et al. 2000).

\section{VULNERABILITY OF CONTROL AND AD LYMPHOBLASTS TO SERUM DEPRIVATION}

Lymphoblasts from AD subjects were found to be more resistant to serum withdrawal (de las Cuevas et al. 2005, Bartolomé et al. 2007). In control cells, there was a progressive appearance of cell death after $24 \mathrm{~h}$ of serum starvation. However, little cell death, as assessed by decreasing levels of MTT reduction was observed in AD cells even after $96 \mathrm{~h}$ of serum deprivation (de las Cuevas et al. 2005, Bartolomé et al. 2007). Selective impairment of the mechanisms involved in cell death has been also reported in fibroblasts from $\mathrm{AD}$ patients. The protective mechanism of $\mathrm{AD}$ fibroblasts against $\mathrm{H}_{2} \mathrm{O}_{2}$ was related to an impairment of cell cycle arrest and a diminished induction of apoptosis (Uberti et al. 2002).

The lower sensitivity of AD lymphoblasts to serum withdrawal was associated with changes in the balance of pro- and anti-apoptotic proteins. Moreover it was shown that the survival of AD cells was accompanied by enhanced $\mathrm{p} 21$ content as compared with that of control cells (Bartolomé et al. 2009b). A number of recent studies pointed out that in addition to being an inhibitor of cell proliferation, p21 may protect cells from apoptosis (Gartel and Radhakrishnan 2005). For example, it has been reported that up-regulation of p21 blocked the oxidative stress-induced death of human myeloma U266 cells (Kim et al. 2001) and that inducible expression of exogenous p21 render glioblastoma cells resistant to chemotherapy drugs (Ruan et al. 1998). Thus the increase in p21 cellular content in AD lymphoblasts may confer these cells a survival advantage.

\section{SIGNALLING PATHWAYS AND MEDIATORS INVOLVED IN INCREASED PROLIFERATION AND SURVIVAL OF AD LYMPHOCYTES}

Since dysregulation of calcium homeostasis is among the major cellular alterations in AD (Thibault et al. 2007) we investigated whether alterations in the 
major cellular $\mathrm{Ca}^{2+}$-binding protein, calmodulin $(\mathrm{CaM})$ were involved in the altered cellular response of AD lymphoblasts. We found that two structurally unrelated antagonists of CaM, like calmidazolium (CMZ) and W-7, inhibited the proliferation of lymphoblasts exclusively from AD patients (Urcelay et al. 2001, de las Cuevas et al. 2003).

The CaM antagonists were also able to revert the resistance of AD lymphoblasts to cell death induced by serum deprivation (de las Cuevas et al. 2005, Bartolomé et al. 2007). Therefore, CaM seems to play a pivotal role in transmitting proliferative/survival signals from the plasma membrane to the nucleus. Whether CaM contributes to cell proliferation or apoptosis may depend on cellular CaM levels and/or activity, as well as the presence of growth-stimulatory signals.

The combination of CaM antagonist and specific inhibitors of intracellular pathways potentially implicated in the regulation of cell proliferation and apoptosis, revealed the interaction of $\mathrm{Ca}^{2+} / \mathrm{CaM}$ with $\mathrm{PI} 3 \mathrm{~K} / \mathrm{Akt}$ and ERK1/2 pathways in the presence or in the absence of serum, respectively. Table I shows how, in contrast to the selective effect of CMZ, preventing the enhanced stimulation of $\mathrm{AD}$ cells, Ly294002, the inhibitor of PI3K/Akt, decreased proliferation of both control and $\mathrm{AD}$ lymphoblasts. SB202190, the inhibitor of p38, and PD98059, inhibitor of ERK1/2 had no effect on cell proliferation. However, treatment of control cells with PD98059 prevented cell death induced by serum starvation (Table I). This inhibitor had no effect in $\mathrm{AD}$ cells, but blunted the effects of $\mathrm{CMZ}$ inducing apoptosis in these cell lines. PI3K/Akt activity, as assessed by increased Akt phosphorylation, was found to be enhanced in AD cells following serum stimulation, compared with the activity observed in control cells (Muñoz et al. 2008a, Bartolomé et al. 2009a, b). In contrast a reduced sustained phosphorylation of ERK1/2 was observed in AD cells upon serum deprivation (Bartolomé et al. 2007). Both overactivation of PI3K/Akt and downregulation of ERK1/2 pathways in AD cells were prevented by CaM antagonists (Bartolomé et al. 2007, Muñoz et al. 2008a)

The $\mathrm{Ca}^{2+} / \mathrm{CaM}$ dependent overactivation of PI3K/Akt appears to be the upstream event in the serum-mediated enhanced proliferation of $\mathrm{AD}$ lymphoblasts. The CaM antagonists and the inhibitor of PI3K/Akt have similar effects in p27 phosphorylation at Thr187, and protein degradation (Muñoz et al. 2008a). It was reported that overactivation of PI3K/Akt in AD cells may favor the CyclinE/CDK2-mediated phosphorylation of p27 at Thr187. In addition, PI3K/Akt phosphorylate other p27 residues (Thr157, Thr159), which are important in controlling the nucleo-cytoplasmic traffic of p27 (Liang et al. 2002). The exclusion of p27 from the nucleus would then facilitate its degradation by the proteasome (Muñoz et al. 2008a,b) and thus relieve cyclinE/CDK2 kinase activity from $\mathrm{p} 27$ inhibition. In fact, it was observed that $\mathrm{pRb}$ hyperphosphorylation, $\mathrm{E} 2 \mathrm{~F}$, and cyclinE/CDK2 activities, as well as p27 content, were all affected by CaM antagonists (de las Cuevas et al. 2003, 2005, Muñoz et al. 2008a, b). On the other hand, the $\mathrm{Ca}^{2+} / \mathrm{CaM}$ dependent down regulation of ERK1/2 seems to be the key event in protecting AD cells from serum deprivation-induced cell death (Bartolomé et al. 2007). By decreasing the activity of ERK1/2, it induces the overexpression of p21 protein, which in turn blocks the serum withdrawal-induced apoptosis (Bartolomé et al. 2009b). Interestingly, it was found that the CaM binding proteins CaMKII and calcineurin are not involved in the serum-enhanced proliferation of $\mathrm{AD}$ lymphoblasts (de las Cuevas et al. 2003, Muñoz et al. 2008a). However CaMKII seems to play an important role in controlling cell survival under serum deprivation, since either $\mathrm{CaM}$ antagonists or the CaMKII inhibitor KN-62 sensitize AD cells to death triggered by the absence of growth stimulatory signals (Bartolomé et al. 2007). CaM antagonists had no effect in control cells, suggesting a threshold for $\mathrm{CaM}$ activation as the survival signal (de las Cuevas et al. 2005, Bartolomé et al. 2007, Muñoz et al. 2008a). In fact, higher CaM content was found in lymphoblasts from $\mathrm{AD}$ patients (Muñoz et al. 2008b).

As reported for other cell types (Pérez-García et al. 2004), we were able to observe that CaM binds to the p85a subunit of PI3K (Muñoz et al. 2008b). Therefore, CaM could contribute to PI3K overactivation in AD cells through this mechanism, as association of CaM with the SH2 domain in $\mathrm{p} 85$ leads to PI3K activation (Pérez-García et al. 2004).

The mechanism(s) by which CaM downregulates the ERK1/2 pathway in AD lymphoblasts is not yet known, thought a mechanism of association of CaMKII with Ras-Raf-1/MEK/ERK1/2 seems likely. This issue is currently under investigation in our laboratory.

In summary, our work revealed a functional relationship between $\mathrm{Ca}^{2+} / \mathrm{CaM}$ and PI3K/Akt or ERKs in serum-induced signalling in immortalized lymphocytes, controlling cell fate (proliferation/death or survival) depending on growth factor availability. The proposed scenario is represented schematically in Fig. 1.

Finally, it is worth mentioning that a deregulation of both PI3K/Akt and ERK1/2 signalling pathways has been reported in $\mathrm{AD}$ brains. Increased 
de las Cuevas et al.: Cell cycle and Alzheimer's disease

Table I. Influence of signalling pretubation on cell proliferation/cell death.

\begin{tabular}{lcc}
\hline Treatment & Control & AD \\
\hline & Inhibition of cell proliferation (\%) & - \\
$+10 \%$ FBS & - & $41 \pm 5$ \\
$20 \mu \mathrm{M} \mathrm{Ly} 294002$ & $35 \pm 3$ & $8 \pm 5$ \\
$20 \mu \mathrm{M}$ PD98059 & $2 \pm 4$ & $5 \pm 3$ \\
$20 \mu \mathrm{M} \mathrm{SB} 202190$ & $6 \pm 4$ & $30 \pm 3^{*}$ \\
$1 \mu \mathrm{M} \mathrm{CMZ}$ & $4 \pm 2$ & $36 \pm 5$ \\
$1 \mu \mathrm{M} \mathrm{CMZ}+20 \mu \mathrm{M}$ Ly294002 & $33 \pm 4$ & \\
\hline & Cell survival (\%) & $92 \pm 5^{\ddagger}$ \\
$-10 \% \mathrm{FBS}$ & $69 \pm 1$ & $87 \pm 2$ \\
$20 \mu \mathrm{M} \mathrm{Ly} 294002$ & $71 \pm 4$ & $92 \pm 9$ \\
$20 \mu \mathrm{M} \mathrm{PD} 98059$ & $96 \pm 2^{\ddagger}$ & $87 \pm 6$ \\
$10 \mu \mathrm{M} \mathrm{SB} 202190$ & $66 \pm 6$ & $61 \pm 6$ \\
$1 \mu \mathrm{M}$ CMZ & $60 \pm 3$ & $87 \pm 6$ \\
$1 \mu \mathrm{M}$ CMZ $+20 \mu \mathrm{M}$ PD98059 & $93 \pm 6^{\ddagger}$ & \\
\hline
\end{tabular}

Lymphoblasts from control and AD individuals were seeded at an initial density of $1 \times 10^{6} / \mathrm{ml}$ on day 0 , in the presence or in the absence of FBS, and treated with the indicated concentrations of drugs for 3 days. Cell survival was expressed as $\%$ of cells at day 0 . Values shown are the mean 6 SEM for 4-6 observations.

$* \mathrm{p}<0.05$ significantly different from control cells; $\$ \mathrm{p}<0.05$ significantly from untreated AD cells.

phospho-Akt (Ser473) has been detected in AD temporal cortex, accompanied by increased levels of phosphorylation of Akt substrates such as GSK3, mTOR, tau and lower levels of p27 (Griffin et al. 2005). Increased phosphorylated p27 (Thr 187) has been also found in AD brains. Importantly, Thr187-p27 shows a considerable overlap with tau-positive neurofibrillary pathology, including neurofibrillary tangles and dystrophic neuritis (Ogawa et al. 2003). On the other hand, ERK1/2 activation has been shown in degenerative neurons in close association with neurofibrillary tangles, suggesting the implication of this pathway in AD pathogenesis (Knowles et al. 1999).

Thus, our results obtained in peripheral cells from AD patients, demonstrated that dysfunction of PI3K/Akt, and ERK1/2 signalling also occur outside the CNS, supporting the hypothesis that AD has systemic expression at cellular and molecular levels.
Therefore, peripheral cells from patients may be a potential useful surrogate for diagnosis, prognosis and therapeutic monitoring of $\mathrm{AD}$.

While most of the studies on AD lymphocytes had been focused on detecting disease-specific changes that may serve as biomarkers, the clinical consequences, if any, of the enhanced proliferative response of lymphocytes in $\mathrm{AD}$ patients, remain to be established, as well as the role that they may play in the chronic inflammation associated with this disease.

\section{CONCLUSIONS}

Cell cycle disturbances are evident in non-neuronal cells from AD patients. While the precise origins of cell cycle alterations are not fully understood, a complex interaction of $\mathrm{Ca}^{2+} / \mathrm{CaM}$ with the PI3K/Akt 


\section{Growth Stimulatory Signals \\ Serum Deprivation}

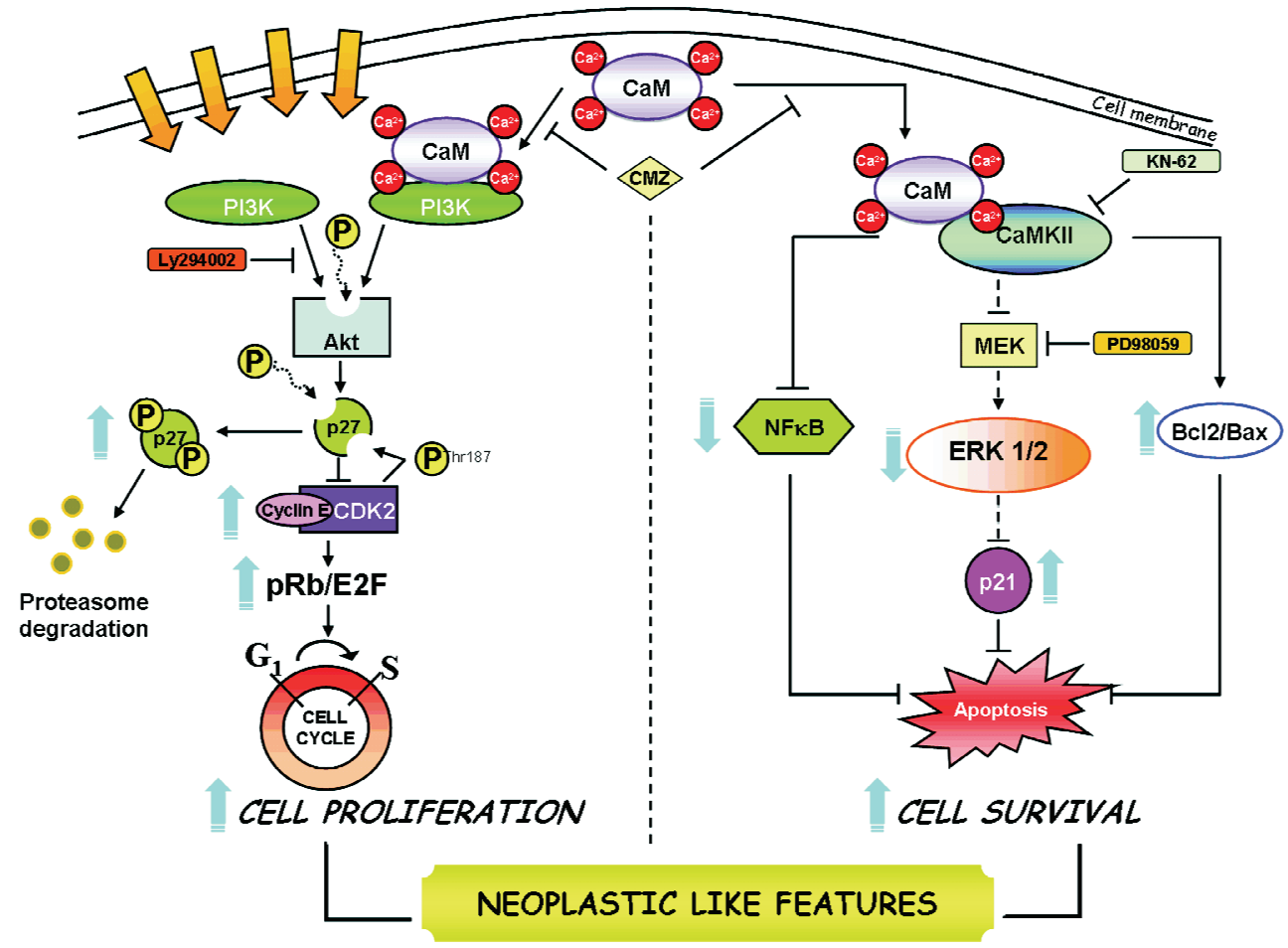

Fig. 1. Depiction of the proposed signalling pathways altered in AD lymphoblasts.

In $\mathrm{AD}$ cells, increased levels of $\mathrm{CaM}$ synergise with serum stimulation and promote overactivation of PI3K/Akt leading to enhanced p27 degradation, and activation of cyclin/CDK/pRb/E2F, therefore favouring, the progression of cells through the cell cycle. In the absence of serum, the $\mathrm{Ca}^{2+} / \mathrm{CaM}$-binding protein, CaMKII, decreases the serum-deprivation induced NF- $\mathrm{KB}$ and ERK1/2 activation in comparison with control cells, and increases the cellular content of $\mathrm{p} 21$, which then seems to protect AD lymphoblasts from apoptosis induced by the absence of trophic support.

and ERK1/2 pathways seems to be the master regulator of cell survival, controlling cell proliferation or preventing apoptosis depending on growth conditions. Two cell cycle regulatory proteins, the CDK inhibitors, p27 and p21, are ultimately responsible for the enhanced proliferation and increased resistance to cell death, respectively. Whereas downregulation of p27 in a $\mathrm{Ca}^{2+} / \mathrm{CaM}$-dependent manner induces the enhanced proliferative response of immortalized lymphocytes from AD patients, upregulation of $\mathrm{p} 21$ seems to help AD cells to escape from serum deprivation-induced apoptosis. The distinct cell cycle and apoptosis control in lymphoblastoid cells from AD patients offer a noninvasive tool for investigating the pathogenesis of $\mathrm{AD}$ and suggest a number of molecular targets for potential AD therapies.

\section{ACKNOWLEDGMENTS}

We are grateful to former members of the laboratory involved in cell lines generation and ionic homeostasis studies. We would like to thank to all patients, their families and clinicians involved in this study. Work in the authors's laboratory has been supported from grants from the Spanish Fondo de Investigaciones Sanitarias (FIS 01/1194 and PI040312), the Spanish Ministry of Science and Innovation (SAF 2003-01458 and SAF 2007-62405), and the Fundación E. Rodríguez Pascual. 


\section{REFERENCES}

Arendt T: Synaptic plasticity and cell cycle activation in neurons are alternative effector pathways: the 'Dr. Jekyll and Mr. Hyde concept' of Alzheimer's disease or the yin and yang of neuroplasticity, Prog Neurobiol 71:83-248, 2003.

Bartolomé F, de las Cuevas N, Muñoz U, Bermejo F, Martín-Requero A: Impaired apoptosis in lymphoblasts from Alzheimer's disease patients: cross-talk of $\mathrm{Ca}^{2+} /$ calmodulin and ERK1/2 signalling pathways. Cell Mol Life Sci 64:1437-1448, 2007.

Bartolomé F, Muñoz U, Esteras N, Esteban J, Bermejo-Pareja F, Martín-Requero A: Distinct regulation of cell cycle and survival in lymphocytes from patients with Alzheimer's disease and amyotrophic lateral sclerosis. Int $\mathbf{J}$ Clin Exp Pathol 2:390-398, 2009a.

Bartolomé F, Muñoz U, Esteras N, Alquezar C, Collado A, Bermejo-Pareja F, Martín-Requero A: HMG-CoA reductase inhibitor simvastatin overcomes the resistance to serum withdrawal-induced apoptosis of lymphocytes from Alzheimer's disease patients. XXXII SEBMM meeting, Oviedo, Spain 2009b.

Bertram L, McQueen MB, Mullin K, Blacker D, Tanzi RE: Systematic meta-analyses of Alzheimer disease genetic association studies: the AlzGene database. Nat Genet 39:17-23, 2007.

Casoli T, Di Stefano G, Giorgetti B, Balietti M, Recchioni R, Moroni F, Marcheselli F, Bernardini G, Fattoretti P, Bertoni-Freddari C: Platelet as a physiological model to investigate apoptotic mechanisms in Alzheimer beta-amyloid peptide production. Mech Ageing Dev 129:154-162, 2008.

de las Cuevas N, Urcelay E, Hermida OG, Saíz-Diaz RA, Bermejo F, Ayuso MS, Martín-Requero A: $\mathrm{Ca}^{2+} /$ calmodulin-dependent modulation of cell cycle elements $\mathrm{pRb}$ and $\mathrm{p} 27 \mathrm{kip} 1$ involved in the enhanced proliferation of lymphoblasts from patients with Alzheimer dementia. Neurobiol Dis 13:254-263, 2003

de las Cuevas N, Muñoz U, Hermida OG, Martín-Requero A: Altered transcriptional regulators in response to serum in immortalized lymphocytes from Alzheimer's disease patients. Neurobiol Aging 26:615-624, 2005.

Etcheberrigaray R, Ibarreta D: Ionic channels and second messenger alterations in Alzheimer's disease. Relevance of studies in nonneuronal cells. Rev Neurol 33:740-749, 2001.

Gartel AL, Radhakrishnan SK: Lost in transcription: p21 repression, mechanisms, and consequences. Cancer Res 65:3980-3985, 2005.
Griffin RJ, Moloney A, Kelliher M, Johnston JA, Ravid R, Dockery P, O'Connor R, O'Neill C: Activation of Akt/PKB, increased phosphorylation of Akt substrates and loss and altered distribution of Akt and PTEN are features of Alzheimer's disease pathology. J Neurochem 93:105-117, 2005.

Jellinger KA: Challenges in neuronal apoptosis. Curr Alzheimer Res 3:377-391, 2006.

Herrup K, Yang Y: Cell cycle regulation in the postmitotic neuron: oxymoron or new biology? Nat Rev Neurosci 8:368-378, 2007.

Kim DK, Cho ES, Lee SJ, Um HD: Constitutive hyperexpression of p21(WAF1) in human U266 myeloma cells blocks the lethal signalling induced by oxidative stress but not by Fas. Biochem Biophys Res Commun 289:34-38, 2001.

Knowles RB, Chin J, Ruff CT, Hyman BT: Demonstration by fluorescence resonance energy transfer of a close association between activated MAP kinase and neurofibrillary tangles: implications for MAP kinase activation in Alzheimer disease. J Neuropathol Exp Neurol 58:1090-1098. 1999.

Kruman II, Wersto RP, Cardozo-Pelaez F, Smilenov L, Chan SL, Chrest FJ, Emokpae R Jr., Gorospe M, Mattson MP: Cell cycle activation linked to neuronal cell death initiated by DNA damage. Neuron 41:549-561, 2004.

Lee HG, Casadesus G, Nunomura A, Zhu X, Castellani RJ, Richardson SL, Perry G, Felsher DW, Petersen RB, Smith MA: The neuronal expression of MYC causes a neurodegenerative phenotype in a novel transgenic mouse. Am J Pathol 174:891-897, 2009a.

Lee HG, Casadesus G, Zhu X, Castellani RJ, McShea A, Perry G, Petersen RB, Bajic V, Smith MA: Cell cycle re-entry mediated neurodegeneration and its treatment role in the pathogenesis of Alzheimer's disease. Neurochem Int 54:84-88, 2009b.

Liang J, Zubovitz J, Petrocelli T, Kotchetkov R, Connor MK, Han $\mathrm{K}$, Lee $\mathrm{JH}$, Ciarallo $\mathrm{S}$, Catzavelos C, Beniston R, Franssen E, Slingerland JM: PKB/Akt phosphorylates p27, impairs nuclear import of p27 and opposes p27-mediated G1 arrest. Nat Med 8:1153-1160, 2002.

McShea A, Zelasko DA, Gerst JL, Smith MA: Signal transduction abnormalities in Alzheimer's disease: evidence of a pathogenic stimuli. Brain Res 815:27-242, 1999.

McShea A, Lee HG, Petersen RB, Casadesus G, Vincent I, Linford NJ, Funk JO, Shapiro RA, Smith MA: Neuronal cell cycle re-entry mediates 
Alzheimer disease-type changes. Biochim Biophys Acta 1772:467-472, 2007.

Milward EA, Papadopoulos R, Fuller SJ, Moir RD, Small D, Beyreuther K, Masters CL: The amyloid protein precursor of Alzheimer's disease is a mediator of the effects of nerve growth factor on neurite outgrowth. Neuron 9:29-37, 1992.

Mittnacht S: Control of pRB phosphorylation. Curr Opin Genet Dev 8:21-27, 1998.

Morrissette DA, Parachikova A, Green KN, LaFerla FM: Relevance of transgenic mouse models to human Alzheimer disease. J Biol Chem 284:6033-6037, 2009.

Mosch B, Morawski M, Mittag A, Lenz D, Tarnok A, Arendt T: Aneuploidy and DNA replication in the normal human brain and Alzheimer's disease. J Neurosci 27:6859-6867, 2007.

Muñoz U, de las Cuevas N, Bartolomé F, Hermida OG, Bermejo F, Martín-Requero A: The cyclopentenone 15-deoxy-delta $(12,14)$ prostaglandin $\mathrm{J}_{2}$ inhibits $\mathrm{G} 1 / \mathrm{S}$ transition and retinoblastoma protein phosphorylation in immortalized lymphocytes from Alzheimer's disease patients. Exp Neurol 195:508-517, 2005.

Muñoz U, Bartolomé F, Bermejo F, Martín-Requero A: Enhanced proteasome-dependent degradation of the CDK inhibitor p27(kip1) in immortalized lymphocytes from Alzheimer's dementia patients. Neurobiol Aging 29:1474-1484, 2008a.

Muñoz U, Bartolomé F, Esteras N, Bermejo-Pareja F, Martín-Requero A: On the mechanism of inhibition of p27 degradation by 15-deoxy-Delta12,14-prostaglandin $\mathrm{J}_{2}$ in lymphoblasts of Alzheimer's disease patients. Cell Mol Life Sci 65:3507-3519, 2008b.

Nagy Z, Esiri MM, Smith AD: The cell division cycle and the pathophysiology of Alzheimer's disease. Neuroscience 87:731-739, 1998.

Nagy Z, Combrinck M, Budge M, McShane R: Cell cycle kinesis in lymphocytes in the diagnosis of Alzheimer's disease, Neurosci Lett 317:81-84, 2002.

Neve RL, McPhie DL: The cell cycle as a therapeutic target for Alzheimer's disease. Pharmacol Ther 111:99-113, 2006.

Ogawa O, Lee HG, Zhu X, Raina A, Harris PL, Castellani RJ, Perry G, Smith MA: Increased p27, an essential component of cell cycle control, in Alzheimer's disease. Aging Cell 2:105-110, 2003.

Pérez-García MJ, Ceña V, de Pablo Y, Llovera M, Comella JX, Soler RM: Glial cell line-derived neurotrophic factor increases intracellular calcium concentration. Role of calcium/calmodulin in the activation of the phosphatidylinositol 3-kinase pathway. J Biol Chem 279:6132-6142, 2004.

Ruan S, Okcu MF, Ren JP, Chiao P, Andreeff M, Levin V, Zhang W: Overexpressed WAF1/Cip1 renders glioblastoma cells resistant to chemotherapy agents 1,3-bis(2-chloroethyl)1-nitrosourea and cisplatin. Cancer Res 58:1538-1543, 1998.

Sala SG, Muñoz U, Bartolomé F, Bermejo F, Martín-Requero A: HMG-CoA reductase inhibitor simvastatin inhibits cell cycle progression at the G1/S checkpoint in immortalized lymphocytes from Alzheimer's disease patients independently of cholesterol-lowering effects. J Pharmacol Exp Ther 324:352-329, 2008.

Stewart WF, Kawas C, Corrada M, Metter EJ: Risk of Alzheimer's disease and duration of NSAID use. Neurology 48:626-632, 1997.

Strittmatter WJ, Weisgraber KH, Huang DY, Dong LM, Salvesen GS, Pericak-Vance M, Schmechel D, Saunders AM, Goldgaber D, Roses AD: Binding of human apolipoprotein $\mathrm{E}$ to synthetic amyloid beta peptide: isoform-specific effects and implications for late-onset Alzheimer disease. Proc Natl Acad Sci USA 90:8098-8192, 1993.

Tatebayashi Y, Takeda M, Kashiwagi Y, Okochi M, Kurumadani T, Sekiyama A, Kanayama G, Hariguchi S, Nishimura T: Cell-cycle-dependent abnormal calcium response in fibroblasts from patients with familial Alzheimer's disease, Dementia 6:9-16, 1995.

Thibault O, Gant JC, Landfield PW: Expansion of the calcium hypothesis of brain aging and Alzheimer's disease: minding the store. Aging Cell 6:307-317, 2007.

Uberti D, Carsana T, Bernardi E, Rodella L, Grigolato P, Lanni C, Racchi M, Govoni S, Memo M: Selective impairment of p53-mediated cell death in fibroblasts from sporadic Alzheimer's disease patients. J Cell Sci 115:3131-3138, 2002.

Ueberham U, Arendt T: The expression of cell cycle proteins in neurons and its relevance for Alzheimer's disease. Curr Drug Targets CNS Neurol Disord 4:293-306, 2005.

Urcelay E, Ibarreta D, Parrilla R, Ayuso MS, Martín-Requero A: Enhanced proliferation of lymphoblasts from patients with Alzheimer dementia associated with calmodulin-dependent activation of the $\mathrm{Na}^{+} / \mathrm{H}^{+}$exchanger. Neurobiol Dis 8:289-298, 2001.

Weinberg RA: The retinoblastoma protein and cell cycle control. Cell 81:323-330, 1995.

Webber KM, Raina AK, Marlatt MW, Zhu X, Prat MI, Morelli L, Casadesus G, Perry G, Smith MA: The cell cycle in Alzheimer disease: a unique 
target for neuropharmacology. Mech Ageing Dev 126:1019-1025, 2005.

Weishaupt JH, Neusch C, Bähr M: Cyclin-dependent kinase 5 (CDK5) and neuronal cell death. Cell Tissue Res 312:1-8, 2003.

Wolozin B, Kellman W, Ruosseau P, Celesia GG, Siegel G: Decreased prevalence of Alzheimer disease associated with 3-hydroxy3-methyglutaryl coenzyme A reductase inhibitors. Arch Neurol 57:1439-1443, 2000.

Yang Y, Varve NH, Lamb BT, Herrup K: Ectopic cell cycle events link human Alzheimer's disease and amyloid precursor protein transgenic mouse models. J Neurosci 26:775-784, 2006.
Yang Y, Geldmacher DS, Herrup K: DNA replication precedes neuronal cell death in Alzheimer's disease. J Neurosci 21:2661-2668, 2001.

Żekanowski C, Wojda U: Aneuploidy, chromosomal missegregation, and cell cycle reentry in Alzheimer's disease. Acta Neurobiol Exp (Wars) 69:232-253, 2009.

Zhou X, Jia J: P53-mediated G1/S checkpoint dysfunction in lymphocytes from Alzheimer's disease patients. Neurosci Lett 468:320-325, 2010.

Zhu X, Lee HG, Perry G, Smith MA: Alzheimer disease, the two-hit hypothesis: an update. Biochim Biophys Acta 1772:494-502, 2007. 